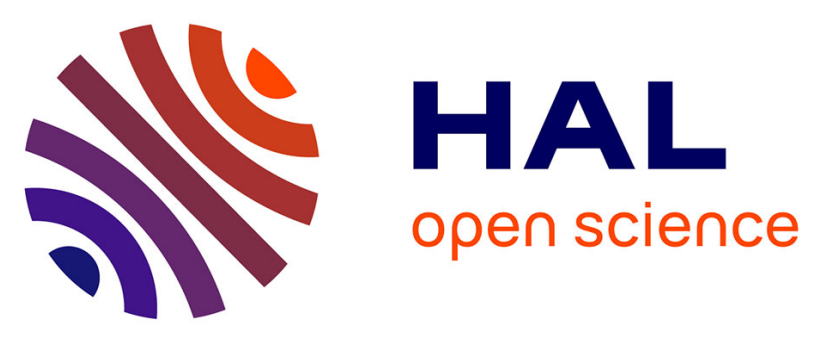

\title{
Is forest regeneration good for biodiversity? Exploring the social dimensions of an apparently ecological debate
} Cécile Barnaud, Anke Fischer, Sam Staddon, Kirsty Blackstock, Clémence

Moreau, Esteve Corbera, Alison Hester, Raphael Mathevet, Annie Mckee, Joana Reyes, et al.

\section{To cite this version:}

Cécile Barnaud, Anke Fischer, Sam Staddon, Kirsty Blackstock, Clémence Moreau, et al.. Is forest regeneration good for biodiversity? Exploring the social dimensions of an apparently ecological debate. Environmental Science \& Policy, 2021, 120, pp.63-72. 10.1016/j.envsci.2021.02.012 . hal-03184480

\author{
HAL Id: hal-03184480 \\ https://hal.inrae.fr/hal-03184480
}

Submitted on 16 Jul 2021

HAL is a multi-disciplinary open access archive for the deposit and dissemination of scientific research documents, whether they are published or not. The documents may come from teaching and research institutions in France or abroad, or from public or private research centers.
L'archive ouverte pluridisciplinaire $\mathbf{H A L}$, est destinée au dépôt et à la diffusion de documents scientifiques de niveau recherche, publiés ou non, émanant des établissements d'enseignement et de recherche français ou étrangers, des laboratoires publics ou privés.

\section{(ㅇ)(1) $\$$}

Distributed under a Creative Commons Attribution - NonCommercial - NoDerivatives $\mid 4.0$ 


\title{
Is forest regeneration good for biodiversity? Exploring the social dimensions of an apparently ecological debate
}

\author{
Cécile Barnaud*1, Anke Fischer ${ }^{2}$, Sam Staddon ${ }^{3}$, Kirsty Blackstock ${ }^{4}$, Clémence Moreau ${ }^{1}$, \\ Esteve Corbera ${ }^{5,8}$, Alison Hester ${ }^{9}$, Raphaël Mathevet ${ }^{6,7}$, Annie McKee ${ }^{4}$, Joana Reyes ${ }^{5}$, Clélia \\ Sirami ${ }^{1}$ and Antonia Eastwood ${ }^{9}$
}

\section{https://doi.org/10.1016/i.envsci.2021.02.012}

\author{
*Corresponding author: cecile.barnaud@inrae.fr; UMR Dynafor, Inrae, Chemin de Borde Rouge, 31326 Castanet Tolosan, \\ France \\ ${ }^{1}$ UMR Dynafor, INRAE, Toulouse University, 31326 Castanet Tolosan, France \\ ${ }^{2}$ Division of Environmental Communication, Swedish University of Agricultural Sciences, Uppsala, Sweden \\ ${ }^{3}$ School of Geosciences, University of Edimburgh, Scotland, UK \\ ${ }^{4}$ Social, Economic and Geographical Sciences (SEGS) department, James Hutton Institute, AB15 8QH, Aberdeen, Scotland, \\ $U K$, \\ ${ }^{5}$ Institute of Environmental Science and Technology \& Department of Geography, Universitat Autònoma de Barcelona UAB \\ campus, 08193 Bellaterra, Barcelona, Spain \\ ${ }^{6}$ CEFE, Univ Montpellier, CNRS, Univ Paul Valéry Montpellier 3, EPHE, Montpellier, France \\ ${ }^{7}$ IFP, UMIFRE 21 CNRS/MAEE, Pondicherry, India \\ ${ }^{8}$ Institució Catalana de Recerca i Estudis Avançats (ICREA) Pg. Lluís Companys 23, 08010 Barcelona, Spain \\ ${ }^{9}$ Ecological Sciences Department, James Hutton Institute, AB15 8QH, Aberdeen, Scotland, UK,
}

How to cite : Cécile Barnaud, Anke Fischer, Sam Staddon, Kirsty Blackstock, Clémence Moreau, Esteve Corbera, Alison Hester, Raphaël Mathevet, Annie McKee, Joana Reyes, Clélia Sirami, and Antonia Eastwood, 'Is Forest Regeneration Good for Biodiversity? Exploring the Social Dimensions of an Apparently Ecological Debate', Environmental Science \& Policy, 120 (2021), 63-72.

\begin{abstract}
Forest regeneration is a major land-use change in European uplands, and whether or not this is a desirable change for biodiversity is disputed. While this debate seems to be largely situated in the field of natural sciences, this paper aims to also examine its social dimensions. To do so, we adopt a comparative discourse analysis with four cases of protected areas in France, Spain, and Scotland. We draw on a conceptual framework highlighting both the ecological and social factors underpinning the construction of environmental discourses. It notably emphasises the role of interests, ideas and institutions, and the power dynamics underpinning discourse-coalitions. We show how diverging discourses emerged, gained ground, coalesced and competed differently in different contexts, explaining the adoption of seemingly opposite discourses by protected area authorities. These findings reaffirm the need to conceive environmental governance as an on-going deliberative process in order to achieve environmental justice.
\end{abstract}

Key words : political ecology, discourse analysis, comparative study, power, rewilding

\section{Introduction}

In many places across the mountains and uplands of Europe, rural exodus and land abandonment have led to forest regeneration, i.e. the spontaneous regrowth of bushes and trees in former grasslands and moorlands (Reed et al. 2009a). The impact of such forest regeneration on biodiversity is a divisive issue 
among natural scientists (Otero et al. 2015). Some consider it as a threat to biodiversity, arguing that mountain livestock farming delivers open ecosystems of grasslands and moorlands with high levels of biodiversity (MacDonald et al. 2000, O'Rourke et al. 2016). In contrast, over the last two decades, others have started to suggest that forest regeneration should be seen as an opportunity for recovering forest biodiversity (Navarro and Pereira 2012, Merckx and Pereira 2015). This view fits with the rewilding paradigm, which is gaining traction across Europe (Barraud and Périgord 2013, WynneJones et al. 2020). This debate over the desirability of forest regeneration for biodiversity raises the key question of which state of reference should be chosen to decide upon the ecological conditions to be preserved or restored (Baker et al. 2014), in our case either the grasslands and moorlands that have been shaped over the centuries by human activities, or the forests that covered the mountains before such activities were widespread (Friedberg et al. 2000, Lepart et al. 2011).

Political ecology scholarship suggests that claims and debates that seem to be largely situated in the domain of ecological science are actually underpinned by socially constructed discourses (Castree and Braun 2001, Kull et al. 2019). Seeing forest regeneration as a 'success' or as a 'threat' for biodiversity are different social constructions, conveyed by different discourses, which shape actions and policies with different social and environmental consequences (Escobar 1996, Bäckstrand and Lövbrand 2006). On the social side, what is at stake is the future of these uplands, the people who inhabit them and all those who are impacted by forest regeneration dynamics and policies. In many places across Europe land abandonment is negatively perceived by rural populations, who see it as a loss of tradition and identity (Benjamin et al. 2007, Ruskule et al. 2013, van der Zanden et al. 2018). There are, however, divergent views and local tensions over what is considered to be desirable for these uplands, both socially and ecologically (Soliva et al. 2008, Krauß and Olwig 2018, Wynne-Jones et al. 2018, Frei et al. 2020).

To further understand these tensions and debates, there is a need to analyze how discourses on forest regeneration are socially constructed on the ground. This paper aims to examine the role of both social and ecological factors in the construction of these discourses, even where these seem, on the surface, purely ecological discourses. To do so, we adopted a comparative approach with multiple cases, drawing on a common conceptual framework. Although discourse analysis is widely used by social scientists working on human-nature relationships, comparative studies and frameworks in this field are lacking (Leipold et al. 2019). And yet, they allow us to appreciate the influence of context on discourses and to reveal taken for granted ideas in a given context (Robbins 2004).

In this paper, we unpack discourses about forest regeneration amongst a range of stakeholders in four cases located in four protected areas (national and natural parks) in the uplands and mountains of France, Spain and Scotland. In the French and Spanish cases the current dominant conservation paradigm of the park authorities considers forest regeneration in former grasslands and moorlands as a threat to biodiversity and aim to support livestock farming to maintain open landscapes (Lepart et al. 2011, Otero et al. 2015). In the Scottish case, on the contrary, the park authorities frame forest regeneration as beneficial to biodiversity and aim to restore native woodland ${ }^{1}$ habitats.

We recognize that ecological conditions and processes vary across contexts, and that this can, in part, explain the adoption of seemingly opposite discourses by different park authorities. We suggest, however, that social factors and mechanisms also help to explain these divergences. Our conceptual framework notably emphasizes the role of ideas, interests and institutions on the construction of discourses, and sheds light on the power dynamics underpinning discourse-coalitions.

\footnotetext{
${ }^{1}$ In Scotland, the term woodland is often preferred to the term forest when it it refers to woodland expansion projects. However, since the term forest is more commonly used in Europe, we will stick to this term in the remaining of the paper, except when we refer specifically to the interviews conducted in the Scottish case.
} 


\section{Conceptual framework}

Central to political ecology research is the idea that relationships between people and nature are a consequence of power, and that power is often exercised through discourses (Buchanan 2013, Svarstad et al. 2018). Our work draws on the discourse analysis approach developed by Hajer (1995, 2006), who defined a discourse as "a specific ensemble of ideas, concepts and categorisations that is produced, reproduced and transformed in a particular set of practices and through which meaning is given to physical and social realities" (Hajer, 1995, p.44). Key notions in Hajer's approach are storylines and discourse-coalitions. A storyline is defined as a "condensed statement summarizing complex narratives, used by people as shorthand in discussions" (Hajer, 2006, p. 69). For example, when people evoke "the rainforest", this is a shortcut that evokes wider narratives, such as its endangered character and its need for protection (Ockwell and Rydin 2006). An assumption in Hajer's work is that storylines are easily shared by a range of actors, even though the actors' wider visions might diverge. These diverse actors can constitute what is referred to as a discourse-coalition, an alliance among actors who mutually reinforce their discursive power by adopting a common storyline that serves their common interests (Hajer, 2006). Discourse-coalitions and storylines are therefore intimately connected: "in the assumed struggle for discursive hegemony [...], storylines act as the 'discursive cement' that keeps the discourse coalition together" (Ockwell and Rydin 2006).

It is widely acknowledged that discourses and discourse-coalitions do not emerge in a vacuum (Rikoon 2006). Discourses are built by people with different interests and values, through social interactions, within specific contexts. However, although these contextual factors and their influence are acknowledged in most discourse analysis studies, they are rarely conceptualized in a structured way (Leipold et al. 2019). To address this gap, we propose a conceptual framework that illuminates the role of such contextual factors on discourses and discourse-coalitions (Figure 1).

Our framework first acknowledges the role of ecological conditions and processes related to the environmental issue at stake, i.e. in our case the state of habitats, land-use patterns and biodiversity dynamics. Because of their focus on discourses and social construction, political ecologists have been criticized for being too constructivist, and denying the materiality of environmental issues (Crist 2004, Walker 2005, Mathevet et al. 2015). In this paper, we recognize that ecological materiality does matter in the emergence of discourses, especially in the use of ecological arguments. 


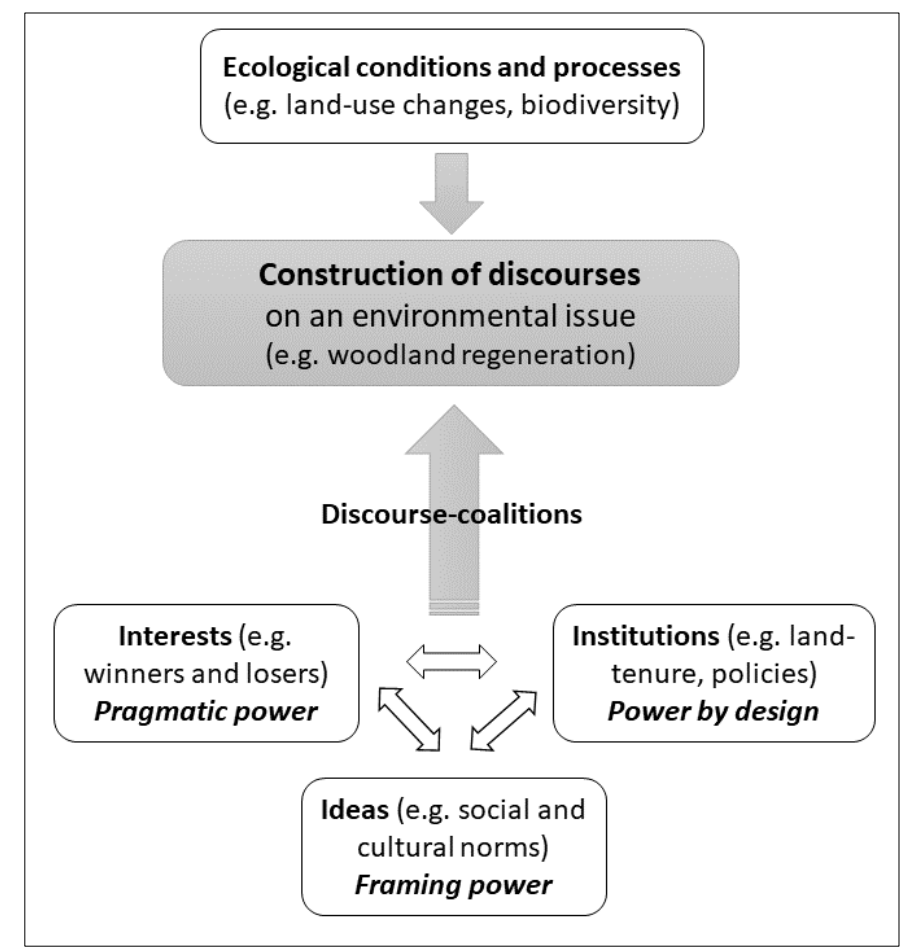

Figure 1. Conceptual framework for analyzing the social and ecological factors underlying the construction of discourses on an environmental issue.

To capture the role of social contextual factors in the way discourses emerge and interact, we turned to the "3-i" framework (Hall 1997), developed in comparative policy analysis, which holds that policymaking in a given context is influenced by stakeholders' interests and ideas, and by institutions (the 3 'i's). Advocates of the 3-i framework explain that whilst these three factors are common in social sciences they are usually studied separately; the benefit of the framework is therefore to explicitly consider their connections (Hall 1997, Kern 2011, Moreau et al. 2019b). We do not study policymaking per se, but we found this conceptual tool helpful in structuring our analysis to explain the influence of the different social factors on discourses construction. Kern (2011) has also combined thisframework with discourse analysis, however he conflated ideas with discourses whilst we hold these conceptually separate, in order to acknowledge the role of cultural factors in the building of discourses. In addition, in line with our political ecology approach, we take the 3-i framework further by integrating a focus on power. Power is a multi-facetted concept, that refers to the ability of actors to affect the behaviours and ideas of others, as well as their ability to control their own life (Ribot and Peluso 2003, Svarstad et al. 2018). In this paper, we draw on the typology elaborated by Morrisson et al. (2019) who identified three facets of power involved in environmental governance, namely 'power by design', 'framing power' and 'pragmatic power', that we linked to the 3 "i"s factors of our framework (Figure 1), as elaborated next.

The first factor, interests, broadly refers to how important a stake is for a given stakeholder. To assess stakeholders' interests, it is critical to identify the winners and losers of a given project or policy, i.e. who benefits from it, and who bears the costs of it (Reed et al. 2009b). The assumption here is that some discourses are being driven (at least partially) by the stakeholders' real or perceived interests, and their desire to influence decision making processes to achieve their own ends. When multiple stakeholders have converging interests, they can form alliances to increase their power in the pursuit of their interests. Although the three types of power identified by Morrisson et al. (2019) are undoubtedly connected to each other, interests are closely linked to 'pragmatic power', that refers to the ability of actors to assert their interests in the daily practice and implementation of rules, through social interactions and often invisible power games. 
The second factor in the 3-i framework, ideas, refers to the social norms and values that drive collective representations about how things should be, and what behaviours are appropriate (Hall 1997, Pomey et al. 2010). This encompasses, for example, the cultural identity of a region, and what heritage should be preserved as priority (Duineveld and Van Assche 2011, del Mármol and Vaccaro 2015). It is assumed here that the emergence of discourses is deeply shaped by these norms. To understand the origin and evolutions of discourses, it is useful to assess how they relate to the dominant cultural norms, how they mobilize these norms in their arguments to increase their legitimacy, or on the contrary how some discourses can be discarded for being too different from them. Ideas (i.e. norms) are however continuously contested, and closely connected to power (Smart 2002). This refers to 'framing power', i.e. the ability of powerful actors to influence the way problems and issues are framed, and to contribute to the norms upon what is considered as legitimate, as a priority or as taken for granted.

The third factor, institutions, is understood in the sense of "humanly devised constraints that structure political, economic and social interactions" (p.97) (North 1991). They are comprised of formal rules codified in some way, as well as informal rules-in-practice, such as traditions and customs (Ostrom 2014). As the latter can merge with the concept of ideas above, we focus on the formal institutions here, which include the legislations and policy instruments generating regulations and incentives on land management, the property right regimes, as well as any formally constituted market or voluntary based agreements that can influence how land is used and managed. These institutions are at the heart of the power dynamics underpinning how discourse-coalitions form and perform. Formal institutions are indeed often the mechanisms by which certain social actors (for example, a public sector agency) can legitimately wield power over other actors. This refers to what Morrisson et al. (2019) named 'power by design', i.e. the legitimate authority of formal institutions to create and impose rules. However, the legitimacy of having power over other actors is conditional and needs to be continually (yet implicitly) renegotiated (Boelens et al. 2015, Blackstock et al. 2017). Alliances and discoursecoalitions can contribute to these negotiation processes.

All in all, the 3 ' $i$ 's together can shed light on the multiple facets of power that underlie the social construction of discourses, notably discourse-coalitions and struggles for discursive domination. Our framework aims to emphasize the combined role of these social factors and the ecological factors in the construction and gaining ground of discourses related to a given environmental issue - in our case forest regeneration in the uplands of Western Europe..

\section{Methodology}

\subsection{Case studies}

Our paper draws on four case studies located in four protected areas in uplands and mountains of France, Spain and Scotland (Table 1). We do not claim that the selected cases are representative of their respective countries. Rather, we chose these cases because they shared some features and yet provided contrasting settings regarding forest regeneration. 
Table 1. Key characteristics of the four case studies

\begin{tabular}{|c|c|c|c|c|}
\hline & $\begin{array}{l}\text { National Park of } \\
\text { the Pyrénées } \\
\text { (France) }\end{array}$ & $\begin{array}{l}\text { National Park of } \\
\text { the Cévennes } \\
\text { (France) }\end{array}$ & $\begin{array}{l}\text { Natural Park of } \\
\text { Montseny } \\
\text { (Catalonya, Spain) }\end{array}$ & $\begin{array}{l}\text { Cairngorms } \\
\text { National Park } \\
\text { (Scotland, UK) }\end{array}$ \\
\hline Area $\left(\mathrm{km}^{2}\right)$ & 1741 & 2993 & 501 & 4528 \\
\hline $\begin{array}{l}\text { Maximum elevation } \\
\text { (m) }\end{array}$ & 3298 & 1699 & 1676 & 1309 \\
\hline $\begin{array}{l}\text { Biogeographic region } \\
\text { (www.eea.eu.int) }\end{array}$ & Alpine & Continental & Mediterranean & Atlantic \\
\hline $\begin{array}{l}\text { Proportion of forest } \\
\text { and } \\
\text { moorland/grassland } \\
\text { areas (CLC 2012) }\end{array}$ & $\begin{array}{l}29 \% \\
50 \%\end{array}$ & $\begin{array}{l}61 \% \\
29 \%\end{array}$ & $\begin{array}{l}93 \% \\
6 \%\end{array}$ & $\begin{array}{l}16 \% \\
40 \%\end{array}$ \\
\hline Dominant tree species & $\begin{array}{l}\text { European beech } \\
\text { (Fagus sylvatica) } \\
\text { Silver fir } \\
\text { (Abies alba) } \\
\text { Mountain pine } \\
\text { (Pinus mugo) }\end{array}$ & $\begin{array}{l}\text { Downy oak } \\
\text { (Quercus } \\
\text { pubescens) } \\
\text { European beech } \\
\text { (Fagus sylvatica) } \\
\text { Silver fir } \\
(\text { Abies alba) }\end{array}$ & $\begin{array}{l}\text { Holm oak (Quercus } \\
\text { ilex) } \\
\text { European beech } \\
\text { (Fagus sylvatica) } \\
\text { Silver fir } \\
\text { (Abies alba) }\end{array}$ & $\begin{array}{l}\text { Scots pine (Pinus } \\
\text { sylvestris) } \\
\text { Silver birch (Betula } \\
\text { pendula) } \\
\text { Downy birch } \\
\text { (Betula pubescens) }\end{array}$ \\
\hline $\begin{array}{l}\text { Population density } \\
\left(\mathrm{hab} / \mathrm{km}^{2}\right)\end{array}$ & 22 & 20 & 68 & 4.1 \\
\hline
\end{tabular}

NB: In the two French cases, the interviews were conducted in sub-areas of the National Park, the Aure Valley in the Pyrénées, and the Mont-Lozère in the Cévennes. However, we give here information regarding the whole protected areas, since the main parks' policies are implemented at this level.

Each site is governed by a national or natural park authority which has duties under national legislation to manage the land for wider society and for visitors, focused on biodiversity conservation as well as cultural heritage. The four sites are classified as Category V under the IUCN classification ${ }^{2}$, which acknowledges that it is the interaction of people and nature over time that has produced an area of distinct character with significant ecological and cultural values. They all attract high numbers of visitors every year, for outdoor recreational activities such as hiking, biking, skiing or naturalist observation, and tourism is the main local economic driver, providing employment in restaurants, accommodation, tours and shops. In terms of landscapes, all cases are upland or mountain landscapes composed of a mix of grassland, moorland and forest, but in different proportions (Table 1), and resulting from different human-nature interactions, as elaborated next.

In the two French cases, traditional livestock farming ('pastoralism') has shaped over centuries open landscapes of grassland and moorland (Lepart et al. 2011, Galop et al. 2013). However, since the 1950s, the decline of livestock farming has resulted in spontaneous forest regeneration inopen landscapes, which succumb to scrub (and later on, trees) due to insufficient grazing pressure (Mottet et al. 2006, Gibon et al. 2010, Lepart et al. 2015). This process began to be negatively perceived from the 1970s, first as a loss of cultural landscapes (Le Floch et al. 2005) and later on as a biodiversity loss (Marty and Lepart 2001). This is still the dominant conservation paradigm in the Pyrénées and Cévennes National Parks, which were created in 1967 and 1970 respectively, and which, since then, have supported livestock farming for maintaining open landscapes (Lepart et al. 2011, Moreau et al. 2019b, Barnaud and Couix 2020).

In the Spanish case, landscapes are dominated by forest, with multiple private forest properties exploiting wood - for charcoal until the 1950s, and mainly cork and timber since then (Boada 2002, Boada et al. 2013). There used to be open areas for crops and livestock farming as well, mainly for local consumption. Since the 1950s, however, the decline of these activities has led to densification of

\footnotetext{
${ }^{2}$ The core zone of the National Park of the Pyrénées is classified as Category II, but our study site is located in the buffer zone which is classified as Category V. The three other parks are entirely classified as Category V.
} 
existing forest and to forest regeneration in open landscapes, resulting in landscape homogenization and reduced biodiversity (Bartolomé et al. 2005, Otero et al. 2015). The Natural Park of Montseny was created in 1977 with the initial idea of protecting nature from human activities, thus they prohibited burning practices used by farmers to clear shrubs in grasslands, which accelerated forest expansion (Bartolomé et al., 2008). However, the conservation paradigm of the park evolved in the early 2000s with a recognition of the role of human activities in the shaping of the natural heritage (Roigé and Estrada 2011). There are nowadays only a few livestock farmers left in the park, but like in the French cases, the park's managers try to reopen former grasslands through mechanical brush cutting, and support the settling of new farmers, for both ecological and socio-cultural reasons.

In the Scottish case, since the $18^{\text {th }}$ century, landscapes have been dominated by moorland. Very large private properties ('estates') are managed for recreational hunting ('sport'), predominantly grouse shooting and deer stalking. This is a traditional leisure activity for landowners and their guests or their paying clients - and the dominant economic activity of the region (Wightman et al. 2002, Glass et al. 2013). Beside these traditional sporting estates, there are also conservation-oriented estates, which can be owned by government bodies, NGOs and / or individuals. Livestock farming also remains an important land-use activity, and is often combined with game management on sporting estates farming is then undertaken by tenant farmers or direct employees of estates (Glass et al. 2013, McKee 2015). In contrast with the previous Spanish and French case studies, there is no large scale spontaneous forest regeneration process occurring, notably because of the high densities of red deer, which browse young trees (Warren 2009, Werritty et al. 2015). The Cairngorms National Park was created in 2003, and the park's authority has set as a priority the restoration of native forest habitats for biodiversity, by culling deer to reduce their densities, fencing some areas with regenerating trees to prevent browsing by deer, and/or planting individual trees to enhance seed dispersal (Dinnie et al. 2012).

\subsection{Data collection and analysis}

Semi-structured interviews were conducted with a range of local land users and managers in the four cases. The French and Spanish cases followed a shared protocol for data collection and analysis. We targeted people with diverse professional or recreational connections to the local environment, including livestock farmers, hunters, park managers (i.e. members of the parks' authorities), other conservation organizations, agricultural advisors, elected representatives, forest managers, tourists and tourism professionals. Interviewees thus provided a diversity of perspectives on forest regeneration issues. Interviews lasted from 1 to $3 \mathrm{~h}$ in general, and aimed at a comprehensive understanding of the interviewees' perception of their surrounding environment, the changes affecting it, and the related social interactions (Appendix 1). The interviews were conducted between 2014 and 2017, with 66 people interviewed in the Pyrénées, 46 in the Cévennes and 23 in Montseny. All interviews were transcribed and qualitatively analysed through a common coding procedure using NVivo software. Single case analyses were published on the two French cases (Moreau et al. 2019b, Barnaud and Couix 2020).

In the Scottish case, social scientists had already conducted similar interviews in the Cairngorms National Park and led analyses on connected topics (Fischer and Marshall 2010, Dinnie et al. 2012, Dinnie et al. 2015, Blackstock et al. 2017, Eastwood et al. submitted). Therefore, in 2018 we organized a workshop (Appendix 2) with a group of Scottish-based scientists to gather their knowledge and identify potential knowledge gaps that had to be addressed for the comparison. The main gaps concerned livestock farmers' views on forest regeneration, and the park managers' views about livestock farming. We thus conducted 8 additional interviews in 2019 to address these gaps, following the same protocol for data collection and analysis as in the French and Spanish cases.

For the purpose of this comparative paper, we reworked all the available data and undertook a joint qualitative thematic analysis based on the conceptual framework presented in section 2 . 


\section{Findings}

\subsection{Main discourses on forest regeneration}

Among the diverse discourses observed across the sites, we identified three main types of recurrent discourses on forest regeneration (Table 2).

Table 2. Estimated prevalence of the different types of discourses within three broad categories of stakeholders

\begin{tabular}{|l|l|l|l|}
\hline $\begin{array}{l}\text { Main discourses on } \\
\text { forest regeneration }\end{array}$ & $\begin{array}{l}\text { Pyrénées National Park \& } \\
\text { Cévennes National Park } \\
\text { (France) }\end{array}$ & $\begin{array}{l}\text { Montseny Natural Park } \\
\text { (Catalonia, Spain) }\end{array}$ & $\begin{array}{l}\text { Cairngorms } \\
\text { Park (Scotland, UK) }\end{array}$ \\
\hline $\begin{array}{l}\text { The end of traditional } \\
\text { livelihoods }\end{array}$ & $\begin{array}{l}\text { Conservationists (+++) } \\
\text { Land-users (+++) } \\
\text { Tourism actors (+++) }\end{array}$ & $\begin{array}{l}\text { Conservationists (+) } \\
\text { Land-users (+) }\end{array}$ & Land-users (+++) \\
\hline A loss of biodiversity & $\begin{array}{l}\text { Conservationists (+++) } \\
\text { Land-users (+++) }\end{array}$ & $\begin{array}{l}\text { Conservationists (+++) } \\
\text { Land-users (+++) }\end{array}$ & $\begin{array}{l}\text { Conservationists (+) } \\
\text { Tourism actors (+) } \\
\text { Land-users (+) }\end{array}$ \\
\hline $\begin{array}{l}\text { A biodiversity gain, more } \\
\text { natural ecosystems }\end{array}$ & $\begin{array}{l}\text { Conservationists (+) } \\
\text { Tourism actors (+) }\end{array}$ & $\begin{array}{l}\text { Conservationists (+) } \\
\text { Tourism actors (+++) }\end{array}$ & $\begin{array}{l}\text { Conservationists (+++) } \\
\text { Tourism actors (+) }\end{array}$ \\
\hline
\end{tabular}

NB 1. This table aims at facilitating the comparison of the sites, and does not allow to picture the richness and diversity of discourses and stakeholders across sites. NB 2. We did not undertake any quantitative analysis so we cannot quantify the prevalence of discourses, but we can give qualitative estimations. The sign (+++) indicates that many people in a stakeholder category adopted this type of discourse. The sign (+) indicates that this type of discourse was adopted by some people in this category, but not many. NB 3. Conservationists include park managers and conservationists from other organizations, including conservation oriented estates; land-users include livestock farmers, hunters, forest owners, and sporting estates; tourism actors including visitors and tourism professionals - other than sporting estates-.

The first type of discourse framed forest regeneration as the decline of traditional livelihoods, and notably as the degradation of landscapes that are central for both local identity and economy. In all sites, we observed similar discourses that depicted forest regeneration as leading to unproductive land. In the French and Spanish cases, many actors mentioned the loss of grass available for livestock; "We lose grass every year" (a livestock farmer, Pyrénées, France), "You can't put the same number of animals any more" (a park manager, Montseny, Spain). In these discourses, forest regeneration was associated with poor land-use practices; grasslands with shrubs were commonly described as "dirty", reflecting "the nature that takes over". These discourses also emphasized the hard work done by previous generations to open and "maintain the landscapes". In the Scottish case, where forest regeneration referred to woodland restoration projects, there was this same idea of spoiling productive land that could otherwise provide food, jobs and incomes. "Trees growing, if they're put in the right place to start with that's fine, but if they're put in land that's capable of growing food..." (a livestock farmer, Cairngorms). Beyond this productive dimension, forest regeneration was also commonly framed as a loss of amenities for society, notably a loss of heritage and identity; "Here, a country with no livestock farming is a dying country. If the landscapes get closed [wooded], it is oppressive, it is less attractive for tourism, it is less rich. It is less... alive" (a livestock farmer, Cévennes, France). The impacts on tourism and local economy were particularly emphasized in the French and Scottish cases, where visitors seemed attracted by open landscapes and long views - while in the Spanish case, visitors mainly came for hiking in forests. All in all, this first type of discourse depicted forest regeneration as reflecting the decline of traditional livelihoods, drawing on economic, social and/or cultural arguments. 
The second type of discourse framed forest regeneration as undesirable because of the associated loss of open ecosystems' biodiversity. In the French and Spanish cases, although there were some divergences among the park managers, this was the dominant discourse adopted within the parks authorities, as well as by others actors such as hunters; "When scrub overgrows, many species are sentenced to disappear" (park manager, Pyrénées, France). In the Spanish case, however, such discourses gained ground more recently than in the French cases; "We used to believe that if there is more forest, there are more birds or mammals. But it is not like that, it is the opposite" (conservationist, Montseny, Spain). The argument thus followed within the French and Spanish park authorities that they should re-open wooded ecosystems, and support livestock farming - but not any kind of livestock farming, it had to be extensive practices that used a maximum of grazing land. In the Scottish case, some park managers mentioned the role of livestock farming on the conservation of species of interest, like curlews and other wading birds. Some conservationists and traditional land managers voiced similar ideas, emphasizing that traditional game management practices such as predator control had shaped and maintained open ecosystems with high levels of biodiversity.

The third type of discourse framed forest regeneration as an ecological success, enabling the recovery of forest biodiversity and a return to more natural ecosystems. In the Scottish case, this was a dominant discourse within the park authority, cautiously connected with the increased interest for rewilding ideas in the country; "You've got the whole rewilding agenda going on [...]. Bigger better connected habitats is what we're aiming for in the park, [...] and a lot of that is about woodland restoration. [...] There is [name of an estate], where they've massively reduced the numbers of deer, and have got fantastic woodland regeneration going on" (park manager, Cairngorms, Scotland). Moorlands were depicted by many conservationists as 'ecological deserts' that if managed less intensively for grouse shooting could support more trees and biodiversity. Other benefits of forest expansion were frequently emphasized, notably carbon storage, but also water regulation, or livestock shelter. In the French cases, discourses in favour of forest regeneration were less frequently (but increasingly) heard, and usually framed in opposition to the dominant conservation paradigm, questioning the spending of public money to maintain open landscapes, and seeing land abandonment as an opportunity for biodiversity; "If you are a fervent defender of nature, the transition towards the closing of landscapes, the development of a forest, that will become in 2000 years an old forest, a mature forest, is it a problem? It is not a problem!" (forest technician of the park, Cévennes, France). This was a more common view in the Spanish case, especially among visitors and new residents who valued pristine nature; "If Montseny was really a natural park, then the forest would be even bigger, a healthy ecosystem, richer in biodiversity." (new resident, Montseny, Spain).

In conclusion, we observed contrasting discourses on forest regeneration both within and across places. While some common features emerged, such as farmers and game managers emphasizing the cultural and ecological benefits of their activities for society, the park authorities across the sites hold apparently opposite discourses on forest regeneration and biodiversity. To further understand these divergences, we analyze in the next sections how these discourses were constructed, emerging from both ecological and social factors.

\subsection{The ecological factors underlying discourses}

There are undoubtedly ecological differences across the sites which can, in part, explain the different discourses held by the park authorities. Four main differences can be highlighted.

First, the landscapes had different proportions of forest, ranging from $93 \%$ in the Spanish case to 16 $\%$ in the Scottish case (Table 1). Second, the current spontaneous vegetation dynamics differed across the sites: while regeneration spontaneously occurs at large scale in the French and Spanish cases because of under-grazing (Bartolomé et al. 2008, Lepart et al. 2015, Vacquie et al. 2015), overgrazing by red deer prevents regeneration in the Scottish case (Werritty et al. 2015). In light of these elements, 
the discourses of the different park managers actually converged in the sense that they all wanted to prevent landscape homogenisation and aimed for a mosaic landscape.

Third, the species richness of open ecosystems varied across sites, notably in relation to various levels of land-use management intensity. In the French and Spanish cases, farming practices were generally very extensive, maintaining permanent grasslands and moorland hosting high levels of biodiversity (Gibon 2005). In the Scottish case, moorlands were often intensively managed (involving drainage, burning, predator control) for grouse shooting, and considered as biodiversity-poor (Werritty et al. 2015). In addition, geology also matters: acidic grasslands and heathlands (that are found in Scotland) are not as species rich as the calcareous grasslands of Southern Europe (Piqueray et al. 2007). These differences can explain in part why the park managers were keener to preserve open landscapes in the French and Spanish cases than in the Scottish one.

Fourth, it can also be argued that the 'regenerated' forests were associated with different species richness across sites. In the French case of the Cévennes, in many places of the park, forest regeneration resulted from the spontaneous expansion of former monospecific plantations of nonnative pine species (Caplat et al. 2006). In the Spanish case, forest had reached levels of densification that were considered as detrimental to forest biodiversity (Bartolomé et al. 2008). In contrast, the type of forest that conservationists aspired to in the Scottish case was open and patchy, with the native Scots pine (Pinus sylvestris) as a key species. Once more, this could explain in part the divergent positions of the park managers across the sites.

However, these ecological factors alone are not sufficient to explain these divergences. Conservation is highly value-driven. In each of the cases, there were debates among local conservationists regarding the species or habitats that should be protected as priority, and some conservationists' positions strongly differed from those of park authorities. In Scotland, some conservationists emphasized that from a European perspective, the preservation of heather moorland should be a priority (these habitats are designated under the European Habitats directive - Natura 2000). In the same way, in the French and Spanish cases, some conservationists argued that forestswere richer in biodiversity than open ecosystems, and therefore that at a global scale, land abandonment in these places increased biodiversity (Navarro and Pereira 2012, Merckx and Pereira 2015). These alternative discourses are ecologically valid, but draw on a different selection of ecological arguments than the dominant discourses of the park authorities. This suggests that there are other social factors of explanation, as elaborated next.

\subsection{The role of ideas, interests and institutions in discourses and discourse-coalitions}

This section presents some of the key elements of ideas, interests and institutions (in this order, for narrative reasons) that played a key role in the construction of discourses across the sites. We then explore how discourses seemed to coalesce and compete differently in the different cases, with a focus on the underlying power dynamics and the interactions among the 3 ' $i$ 's factors.

Regarding ideas, the normative representations of traditional livelihoods, heritage and identity, and their evolution, played in all cases a critical role in the discourses on forest regeneration. In the French mountains, in the early $20^{\text {th }}$ century, livestock farmers were criticized for not respecting natural equilibriums, grasslands were considered as degraded ecosystems due to overgrazing, and massive forest plantation schemes were conducted to restore forest ecosystems (Marty and Lepart 2001). In the 1970s, forest regeneration started to be depicted as a threat, the ecosystem of reference shifted from forest to grassland, in relation to more positive representations of livestock farmers and a desire to preserve their cultural heritage (Friedberg et al. 2000, Marty and Lepart 2001). This social norm was still vivid 40 years later, and strongly anchored in institutions, as illustrated by the designation in 2011 of the agro-pastoral cultural landscape of the Cévennes as a UNESCO World Heritage Site (Moreau et al. 2019b). In the two French cases, the dominant discourses within park authorities were aligned with these norms, but contestations and alternative visions were rising. 
In the Scottish case, the traditional activities of sporting and the associated open landscapes were an important part of the Scottish cultural heritage that stems from the Victorian era (Glass et al. 2013). However, this Victorian heritage was increasingly contested for being unjust, due to the concentration of land ownership and the exclusivity of field sports (Fischer and Marshall 2010, Wightman 2013, Dinnie et al. 2015). The "Caledonian forest" had instead been gradually depicted as a more legitimate landscape. The dominant discourse within the park authority was aligned with these ideas - though $t$ not openly in opposition to the Victorian heritage, due to its economic importance for tourism . Interestingly, the historical event of the Highland clearances - the eviction of small family farmers during the $18^{\text {th }}$ century to the benefits of large private land-owners - which gained symbolic meaning and underlay the contestation of the Victorian heritage, was also used by some farmers as an argument against forest expansion schemes, depicted as "history repeating itself".

In the Spanish case, the identity of Montseny had long been connected to forest - the place was famous for its monumental trees, including a chestnut tree with a canopy of 12-meter diameter. When the park was created in the 1970s, the idea was to protect an exceptional forest ecosystem from negative human impacts, and to enable the inhabitants of the neighbouring city of Barcelona to recharge themselves in nature (Roigé and Estrada 2011). In the early 2000s, there was a shift in the park authority's position, who depicted the traditional agro-sylvo-pastoral land-uses as a heritage to maintain (Otero et al. 2015). However, this heritage was portrayed as something that belonged to the past and that visitors discovered in museums, especially livestock farming. Two opposite ideals seemed to co-exist: the ideal of an untouched forest held by many visitors and new residents, and the vision of a human shaped-landscape that the park tried to promote - but with a lack of support, as we will see next.

While discourses on forest regeneration were influenced by such cultural contexts and social norms, they also reflected stakeholders' interests. In particular, it was in the interests of those who earned their living from farming or shooting to voice discourses framing forest regeneration as a loss of common goods for the whole society (be it biodiversity or cultural heritage). In the French cases, livestock farmers were highly dependent on agri-environmental subsidies that were justified by these positive externalities. In the Scottish case, sporting estates were strongly opposed to forest regeneration, either because of the loss of habitat for game, or because forest expansion policies relied on the reduction of deer populations which meant both a large burden on the estate and less economic gain from deer stalking. As for tenant farmers, their opposition to forest expansion was related to a fear that estate owners would decide to terminate their lease. By contrast, in the Spanish case, the remaining farmers were too few and there was no lobby giving strength to pro-open landscape discourses. Besides, in all cases, there were strong interests related to tourism, the dominant local economic sector, and this contributed to the voicing of different discourses depending on what visitors seemed mostly attracted to - forest in the Spanish case, open landscapes in the French cases, both in the Scottish case depending on the type of tourism. There could also be very pragmatic reasons, such as, in the French case of the Pyrénées, the need to keep the grass short in ski stations to prevent avalanches; "We tomorrow cannot afford to have brush cutters replacing the livestock" (elected representative, Pyrénées, France).

We see here that ideas and interests were sometimes aligned to, and sometimes opposite to the parks' dominant discourses on forest regeneration. To get an understanding of the park authorities' strategy, there is a need to look at the institutional context in which they operated.

Among the formal institutions, our analysis shows the importance of public policies and land-tenure. We did not attempt to delve into an analysis of the various policies underlining forest regeneration, but rather explored how they were perceived and connected to forest regeneration in discourses. The EU Common Agricultural Policy (CAP) direct payments scheme to farmers, with its different national adaptations, supported livestock farming in all cases, and the agri-environmental measures likely influenced the gaining ground of discourses on the richness of grassland biodiversity in all cases. 
However, while the CAP subsidies were generally pictured as essential to maintain livestock farming and prevent forest regeneration in the French cases, in the Spanish case, they were judged insufficient. In the Scottish case, the agricultural policies were not discursively connected to forest regeneration. By contrast, climate change policies were frequently associated to forest regeneration in discourses in the Scottish case, while they were hardly evoked in the French and Spanish cases at the time we conducted the interviews.

Regarding land-tenure, the Scottish and Spanish cases were dominated by large private properties, while the French cases were characterized by high levels of fragmentation, with multiple small landowners, and by the power of elected representatives, since municipalities owned most collective grasslands; "The boss, in the end, is the one who owns the land!" (a livestock farmer, in the Pyrénées, France). An important common feature across sites was that the park authorities did not own the land they had under their duty (or only small portions of it); "If the park owned the land, it would be way easier, we could shape our dream mosaic" (a park manager, Cévennes, France). Although several practices were regulated, for example through permits' systems in the core zones of the French national parks, the regulatory tools of the park managers were generally limited - and even where topdown interventions were possible on paper, authorities were reluctant to use them in practice, in order not to compromise their social acceptance. The park managers thus lacked power by design to make landowners and land-users follow their recommendations. They were only enablers (Blackstock et al. 2017), and needed other sources of power to legitimate and implement their policies.

We will see in the remainder of this section how the park authorities likely relied on strategic alliances of interests to increase their pragmatic power, but also importantly on discourse-coalitions to increase their framing power.

In the French cases, dominant ideas, local stakeholders' interests and national policies all converged in favour of maintaining livestock farming and open landscapes. According to some interviewed conservationists, the park managers made a pragmatic choice in focusing on open ecosystems, since it would have been difficult to implement conservation policies against both local interests and dominant ideas. They thus joined a discourse-coalition around the storyline "closing of landscapes" ("fermeture des milieux" in French), a discursive shortcut implicitly evoking the negative impacts of forest regeneration, and coalescing around the interests of stakeholders who all wanted to maintain open landscapes, but for different reasons - ecological, economic or cultural (Barnaud and Couix 2020). However, this apparent consensus and the discursive hegemony of this storyline had inhibited alternative discourses questioning the amount of public money dedicated to support mountain farming in the name of biodiversity, seeing land abandonment as an opportunity to recover another interesting type of biodiversity; "We lose a habitat of community importance, but we gain another habitat of community importance, so..." (conservationist, Pyrénées, France). Some actors also pointed to the increasing number of deer as a natural means to maintain open landscapes. Whilst such discourses were still taboo in many local arenas in the Pyrénées (Barnaud and Couix 2020), they were increasingly voiced in the Cévennes, creating tensions with and within the park authority (Moreau et al. 2019a).

In the Scottish case, the park managers seemed to implement and legitimate their forest regeneration policies through other types of alliances, drawing less on alliances with traditional land-users than in the French cases. Key local allies were the conservation-oriented estates, notably those who had built a partnership to restore native woodland at landscape scale. Most of these large private estates were owned by conservation NGOs and environmental public bodies, but a private individual had also recently bought several estates with large-scale ambitions for rewilding, which contributed to publicizing rewilding ideas. The discourses in favour of forest regeneration were also strongly anchored in the climate change agenda and affiliated national policies; "The Scottish government have a 10,000 ha a year [woodland] expansion target, and so we are trying to do our bit in the Park" (park manager, Caingorms, Scotland). Finally, this discourse was also aligned with the contestation of the Victorian heritage, and the will to recover the historical Caledonian forest (Dinnie et al. 2015). The different 
elements seemed to fuel a discourse-coalition around the storyline "native woodland" that implicitly evoked the social, political, cultural and ecological legitimacy of woodland restoration. This discoursecoalition and the associated policies clashed with the interests of the economically and politically powerful sporting estates, which used pragmatic power to block some woodland expansion projects, but also framing power, by building a counter discourse highlighting the multiple benefits of game management in terms of heritage, knowledge, local employment and biodiversity (Dinnie et al. 2015). Traditional sporting estates also emphasized that the defenders of woodland restoration were mainly coming from the urban Scottish population, and used this argument to delegitimise their discourses. While the French cases presented a situation of discursive hegemony starting to be contested, in Scotland, there seemed to be an opposition between two dominant and competing discoursecoalitions. The comparison with the French cases also illuminated that livestock farming occupied a surprisingly small place in the Scottish debates on forest regeneration, despite the number of farms in the national park. At the time we conducted the interviews (2019), there was no official strategy of the Cairngorms National Park Authority regarding livestock farming (while there was one for game management and woodland expansion for example). This could be related to the fragility of land tenure of tenant farmers, which results in limited power, but also, in more symbolic terms, to the instrumental place of farming in the Victorian model - e.g. using sheep to attract ticks away from the game.

In the Spanish case, the natural park managers seemed to lack both pragmatic and framing power to legitimate and implement their relatively new policies aimed at supporting livestock farming to slow down forest regeneration. They undertook actions to re-open forest and install new livestock farmers, but these actions often failed, because of a lack of support from both national policies and local stakeholders who did not see forest regeneration as a problem. It seemed that the park managers failed to create or enter a discourse-coalition that could have legitimized their pro-open landscape policies. In this case, the discursive struggles were not structured around "forest" versus "open ecosystems" as in the other cases, but rather around "managed ecosystems" versus "natural ecosystems". On the one side, forest owners and park managers' discourses coalesced around the idea that healthy ecosystems require human interventions. On the other side, there likely was a discoursecoalition combining the ideas that true nature means no human intervention, and that nature belongs to everyone, held by many visitors and new residents, creating tensions with the forest owners. The park managers therefore made an effort to counter this visionthrough "education programmes" for visitors.

\section{Discussion}

Social scientists working on environmental issues are increasingly understanding the nexus of power, knowledge and discourses in environmental debates and policies. However, the recent review of Leipold et al. (2019) suggests that multiple cases discourse analysis and comparative frameworks are lacking (Leipold et al. 2019). Our paper addresses this gap by proposing a conceptual framework that calls attention to the role of ecological and social factors in the construction of discourses on a given environmental issue. It first highlights that diverse ecological contexts can in part explain the use of different ecological arguments - whilst acknowledging that the available knowledge is itself often controversial and that the selection of some ecological arguments (and the discarding of other ones) is highly value-laden. These ecological factors are thus intimately intertwined with social factors. To capture the latter, our framework emphasises the role of interests, ideas, and institutions in the social mechanisms and power dynamics underpinning discursive dynamics.

These social factors have been acknowledged in discourse analysis-based studies, which underline, for example, the connections between interests and discourse-coalitions (Hajer 2006, Ockwell and Rydin 2006), between institutions and discourses (Arts and Buizer 2009, Kern 2011), and between ideas and discourses (Rikoon 2006, Duineveld and Van Assche 2011). The novelty of our approach lies in the joint analysis of interests, ideas and institutions and their connection to power, discourses and discourse- 
coalitions. In doing so, we have modestly aimed to respond to Leipold et al.'s (2019) call for "a more explicit conceptualization of agency, power and materiality" in discourse analysis. Our study shows in particular that there was no clear dichotomy of powerful versus powerless actors. Power relations were more subtle and nuanced. In the Scottish case, for example, the Victorian heritage was contested by public opinion as unfair, but farmers and traditional sporting estates simultaneously claimed that the current environmental policies were unfair to them and failed to recognise local values. Recent theorisations in the field of environmental justice suggest the need to jointly consider three dimensions of justice (Schlosberg 2004, Martin et al. 2016), which interestingly echo the 3 ' $i$ 's of our framework: equity and distributive effects of environmental changes and policies (linked to interests), recognition of the diversity of knowledge and values (linked to ideas), and participation in decision making (linked to institutions).

Applying this framework in a comparative study enabled us to advance the understanding of at least two key issues in environmental governance: the governance of protected areas and the ecological debates over forest regeneration. The evolution of conservation paradigms has led to the multiplication of protected areas that acknowledge the role of people in the shaping of ecosystems of significant ecological value (Gerber and Knoepfel 2008, Mathevet et al. 2016). This requires involving local stakehoders in collaborative modes of governance, in which park authorities are mostly facilitators or "enablers" (Blackstock et al. 2017, Cosson et al. 2017). However, such governance remains challenging in practice and its social mechanisms must be further understood (Corbera et al. 2007, Mathevet et al. 2018). Here, we have specifically shed light on the power struggles underlying the making of discourses by park authorities. In all cases, park managers hardly used regulatory power and rather relied on discourse-coalitions to increase their framing power and legitimate their views and actions. Their different positions on forest regeneration could thus be explained by the different types of alliances they built, with local land-users, public opinion, or national policy-makers.

Our comparative study also increased our understanding of the debates on forest regeneration in European uplands. Theses debates interacted with other, related discourses in dynamic ways. For example, all cases presented some discourses framing forest regeneration as a positive move towards more natural ecosystems, echoing the recent wave of 'rewilding' ideas across Europe (Jørgensen 2015, Deary and Warren 2017). Our analysis showed that this common wave of ideas received different responses in different contexts. In Scotland, for example, rewilding has recently come to focus on woodland restoration, as wildlife reintroductions have become more controversial (Martin et al. submitted). Proponents of forest regeneration could thus form a discourse-coalition with rewilding advocates. At the same time, concerns about 'the second clearances', i.e., the expulsion of people from the Highlands to make space for forests, has weakened the pro-rewilding positions. In the French Pyrénées, by comparison, the rewilding views have long been taboo in local arenas, notably because they echoed the conflicts over the reintroduction of brown bears and were largely perceived as a threat to livestock farming survival (Knight 2016, Barnaud and Couix 2020). In the Spanish case, on the contrary, the park has long been perceived by visitors as "pristine nature" that forest owners are not legitimate to exploit. From our comparative analysis, we suggest that discourses in favour of more natural ecosystems were inhibited by the strength and legitimacy of the heritage linked to traditional land-use activities (livestock farming, game management or forest exploitation). In other words, what drives the motivations and discourses of people who want more natural ecosystems is not only a desire to increase naturalness (Deary \& Warren 2017), but is also linked to the perceived lack of legitimacy of the people who transform these ecosystems - small livestock farmers in the Pyrénées being more legitimate in the eyes of the public opinion in France than Highlands large land owners are in Scotland, or forest owners in the Spanish case. Such legitimacy is itself a social construct though, which can be contested and is constantly evolving, through interactions with other public debates. There are indeed numerous examples of shifts in the historical baseline used by conservationists to establish what ecosystems should be restored (Marty and Lepart 2001, Moreau et al. 2019b). The climate change 
agenda is notably likely reshuffling, or about to reshuffle, the positions and debates on forest regeneration (de Koning et al. 2014).

\section{Conclusion}

Forest regeneration is transforming European uplands, and whether or not this is a desirable change for biodiversty is disputed among people and across places. To explore the social dimensions of this apparently ecological debate, our research unpacked the diverse discourses of forest regeneration across four protected areas in France, Scotland, and Spain. We showed how different discourses emerged, gained ground, coalesced, and competed differently in different ecological and social contexts. In the light of these findings, we assert that fair and transparent environmental governance should acknowledge both the social and ecological factors that underpin the shaping of environmental discourses. It is critical in particular to consider environmental authorities as stakeholders who, like others, can have competing ecological goals, take decisions despite uncertainties, build strategic alliances to legitimise their positions, and eventually adapt and modify their discourses as contexts change. Environmental governance should thus be appraised as an on-going deliberative process in order to achieve environmental justice.

\section{Acknowledgements}

We would like to thank all interviewees for their time and contributions, all the members of the Secoco project, and three reviewers and the editor for their comments on an earlier version of the manuscript. This publication has been written with the support of the AgreenSkills + fellowship programme which has received funding from the EU's Seventh Framework Programme under grant agreement $N^{\circ}$ FP7609398 (PCOFUND-GA-2010-267196); the INRA Metaprogram Ecoserv; the Scottish Government's Strategic Research Programme 2016-2021; the "María de Maeztu" Programme for Units of Excellence of the Spanish Ministry of Science and Innovation (CEX2019-000940-M).

\section{References}

Arts, B. and M. Buizer. 2009. Forests, discourses, institutions: A discursive-institutional analysis of global forest governance. Forest Policy and Economics 11(5):340-347.

Bäckstrand, K. and E. Lövbrand. 2006. Planting Trees to Mitigate Climate Change: Contested Discourses of Ecological Modernization, Green Governmentality and Civic Environmentalism. Global Environmental Politics 6(1):50-75.

Baker, S., K. Eckerberg, and A. Zachrisson. 2014. Political science and ecological restoration. Environmental Politics 23(3):509-524.

Barnaud, C. and N. Couix. 2020. The multifunctionality of mountain farming: Social constructions and local negotiations behind an apparent consensus. Journal of Rural Studies 73:34-45.

Barraud, R. and M. Périgord. 2013. Rewilding Europe: A Renewal of Natural Heritage-making? L'espace géographique 42(3):254-269.

Bartolomé, J., M. Boada, D. Saurí, S. Sánchez, and J. Plaixats. 2008. Conifer dispersion on subalpine pastures in northeastern Spain: characteristics and implications for rangeland management. Rangeland ecology \& management(61):218-225.

Bartolomé, J., J. Plaixats, R. Fanlo, and M. Boada. 2005. Conservation of isolated Atlantic heathlands in the Mediterranean region: effects of land-use changes in the Montseny biosphere reserve (Spain). Biological Conservation 122(1):81-88.

Benjamin, K., A. Bouchard, and G. Domon. 2007. Abandoned farmlands as components of rural landscapes: An analysis of perceptions and representations. Landscape and Urban Planning 83(4):228-244. 
Blackstock, K. L., E. Dinnie, and R. Dilley. 2017. Governing the Cairngorms National Park - Revisiting the neglected concept of authority. Journal of Rural Studies 52:12-20.

Boada, M. 2002. El Montseny, Cinquanta Anys d'Evolució dels Paisatges. Publicacions de l'Abadia de Montserrat, Barcelona, Spain.

Boada, M., J. Puig, and C. Barriocanal. 2013. The Effects of Isolation and Natural Park Coverage for Landrace In situ Conservation: An Approach from the Montseny Mountains (NE Spain). Sustainability(5):654-663.

Boelens, R., J. Hoogesteger, and M. Baud. 2015. Water reform governmentality in Ecuador: Neoliberalism, centralization, and the restraining of polycentric authority and community rulemaking. Geoforum 64:281-291.

Buchanan, K. S. 2013. Contested discourses, knowledge, and socio-environmental conflict in Ecuador. Environmental Science \& Policy 30:19-25.

Caplat, P., J. Lepart, and P. Marty. 2006. Landscape patterns and agriculture: modelling the long-term effects of human practices on Pinus sylvestris spatial dynamics (Causse Mejean, France). Landscape Ecology 21:657-670.

Castree, N. and B. Braun, editors. 2001. Social Nature. Theory, Practice, and Politics. Blackwell, Oxford and New York.

Corbera, E., N. Kosoy, and M. Martínez Tuna. 2007. Equity implications of marketing ecosystem services in protected areas and rural communities: Case studies from Meso-America. Global Environmental Change 17(3-4):365-380.

Cosson, A., C. Therville, R. Mathevet, I. Arpin, and F. Bioret. 2017. Dynamiques d'intégration des espaces naturels protégés en France : une approche comparative entre parcs nationaux et réserves naturelles. Natures Sciences Sociétés 25(3):230-240.

Crist, E. 2004. Against the Social Construction of Nature and Wilderness. Environmental Ethics 26(1):524.

de Koning, J., G. Winkel, M. Sotirov, M. Blondet, L. Borras, F. Ferranti, and M. Geitzenauer. 2014. Natura 2000 and climate change-Polarisation, uncertainty, and pragmatism in discourses on forest conservation and management in Europe. Environmental Science \& Policy 39:129-138.

Deary, H. and C. R. Warren. 2017. Divergent visions of wildness and naturalness in a storied landscape: Practices and discourses of rewilding in Scotland's wild places. Journal of Rural Studies 54(Supplement C):211-222.

del Mármol, C. and I. Vaccaro. 2015. Changing Ruralities: Between Abandonment and Redefinition in the Catalan Pyrenees. Anthropological Forum 25(1):21-41.

Dinnie, E., K. L. Blackstock, and R. Dilley. 2012. Landscapes of Challenge and Change: Contested Views of the Cairngorms National Park. Landscape Research 37(4):451-466.

Dinnie, E., A. Fischer, and S. Huband. 2015. Discursive claims to knowledge: The challenge of delivering public policy objectives through new environmental governance arrangements. Journal of Rural Studies 37:1-9.

Duineveld, M. and K. Van Assche. 2011. The Power of Tulips: Constructing Nature and Heritage in a Contested Landscape. Journal of Environmental Policy \& Planning 13(2):79-98.

Eastwood, A., A. Fischer, A. Hague, and K. Brown. submitted. A cup of tea? - The role of social dimensions in land managers' adaptations to policy change Land Use Policy.

Escobar, A. 1996. Construction nature: Elements for a post-structuralist political ecology. Futures 28(4):325-343.

Fischer, A. and K. Marshall. 2010. Framing the landscape: Discourses of woodland restoration and moorland management in Scotland. Journal of Rural Studies 26(2):185-193.

Frei, T., J. Derks, C. Rodríguez Fernández-Blanco, and G. Winkel. 2020. Narrating abandoned land: Perceptions of natural forest regrowth in Southwestern Europe. Land Use Policy 99:105034.

Friedberg, C., M. Cohen, and N. Mathieu. 2000. Faut-il qu'un paysage soit ouvert ou fermé ? L'exemple de la pelouse sèche du causse Méjan. Nature Sciences Sociétés 8(4):26-42.

Galop, D., D. Rius, and C. Cugny. 2013. Long-term human-environment interactions history in the French Pyrenean Moutains inferred from pollen data. Pages 19-30 in L. Lozny, editor. 
Continuity and Change in Cultural Adaptation to Mountain Environments. Springer-Verlag, New York, USA.

Gerber, J.-D. and P. Knoepfel. 2008. Towards Integrated Governance of Landscape Development. Mountain Research and Development 28(2):110-115, 116.

Gibon, A. 2005. Managing grassland for production, the environment and the landscape. Challenges at the farm and the landscape level. Livestock Production Science 96:11- 31.

Gibon, A., D. Sheeren, C. Monteil, S. Ladet, and G. Balent. 2010. Modelling and simulating change in reforesting mountain landscapes using a social-ecological framework. Landscape Ecology 25:267-285.

Glass, J., M. F. Price, C. Warren, and A. Scott, editors. 2013. Lairs, Land and Sustainability. Scottish perspectives on upland management. Edimburg Press University, Edimburgh.

Hajer, M. 1995. The Politics of Environmental Discourse: Ecological Modernization and the Policy Process. Oxford University Press, Oxford.

Hajer, M. 2006. Doing discourse analysis: coalitions, practices, meaning. . Pages 65-74 in M. Van Den Brink and T. Metze, editors. Words Matter in Policy and Planning: Discourse Theory and Method in the Social Sciences. Ngsurr, Utrecht.

Hall, P. A. 1997. The role of interests, institutions, and ideas in the comparative political economy of the industrialized nations. Pages 174-207 in M. I. Lichbach and A. S. Zuckerman, editors. Comparative politics: Rationality, culture, and structure. Cambridge University Press, Cambridge.

Jørgensen, D. 2015. Rethinking rewilding. Geoforum 65:482-488.

Kern, F. 2011. Ideas, Institutions, and Interests: Explaining Policy Divergence in Fostering 'System Innovations' towards Sustainability. Environment and Planning C: Government and Policy 29(6):1116-1134.

Knight, T. 2016. Rewilding the French Pyrenean Landscape: Can Cultural and Biological Diversity Successfully Coexist? Pages 193-209 in M. Agnoletti and F. Emanueli, editors. Biocultural Diversity in Europe. Springer International Publishing, Cham.

Krauß, W. and K. R. Olwig. 2018. Special issue on pastoral landscapes caught between abandonment, rewilding and agro-environmental management. Is there an alternative future? Landscape Research 43(8):1015-1020.

Kull, C. A., S. L. Harimanana, A. Radaniela Andrianoro, and L. G. Rajoelison. 2019. Divergent perceptions of the 'neo-Australian' forests of lowland eastern Madagascar: Invasions, transitions, and livelihoods. Journal of Environmental Management 229:48-56.

Le Floch, S., A.-S. Devanne, and J.-P. Deffontaines. 2005. "Closing the Landscape": Beyond the Phenomenon, a Brief History of the Social Construct. L'espace géographique 34(1):49-64.

Leipold, S., P. H. Feindt, G. Winkel, and R. Keller. 2019. Discourse analysis of environmental policy revisited: traditions, trends, perspectives. Journal of Environmental Policy \& Planning 21(5):445-463.

Lepart, J., C. Bonnel, C. Lhuillier, and P. Marty. 2015. Conservation de la biodiversité et dynamiques agricoles dans le territoire du Parc National: difficile convergence Dynamiques environnementales 35 .

Lepart, J., P. Marty, and J. Fonderflick. 2011. Landscape dynamics and biodiversity of agro-pastoral landscapes in 'Les Causses'. Fourrages:343-352.

MacDonald, D., J. R. Crabtree, G. Wiesinger, T. Dax, N. Stamou, P. Fleury, J. Gutierrez Lazpita, and A. Gibon. 2000. Agricultural abandonment in mountain areas of Europe: Environmental consequences and policy response. Journal of Environmental Management 59(1):47-69.

Martin, A., B. Coolsaet, E. Corbera, N. M. Dawson, J. A. Fraser, I. Lehmann, and I. Rodriguez. 2016. Justice and conservation: The need to incorporate recognition. Biological Conservation 197:254-261.

Martin, A., A. Fischer, R. McMorran, and M. Smith. submitted. Taming rewilding - from the ecological to the social: how rewilding discourse in Scotland has come to include people. Land Use Policy. 
Marty, P. and J. Lepart. 2001. Forêts et milieux ouverts : anciennes et nouvelles légitimités (Forests and open landscapes : old and new legitimacies). Bulletin de l'Association de géographes français 2001(Juin):177-189.

Mathevet, R., F. Bousquet, C. Larrère, and R. Larrère. 2018. Environmental Stewardship and Ecological Solidarity: Rethinking Social-Ecological Interdependency and Responsibility. Journal of Agricultural and Environmental Ethics 31(5):605-623.

Mathevet, R., N. L. Peluso, A. Couespel, and P. Robbins. 2015. Using historical political ecology to understand the present: water, reeds, and biodiversity in the Camargue Biosphere Reserve, southern France. Ecology and Society 20(4).

Mathevet, R., J. D. Thompson, C. Folke, and F. S. Chapin. 2016. Protected areas and their surrounding territory: socioecological systems in the context of ecological solidarity. Ecological Applications 26(1):5-16.

McKee, A. J. 2015. Legitimising the Laird? Communicative Action and the role of private landowner and community engagement in rural sustainability. Journal of Rural Studies 41:23-36.

Merckx, T. and H. M. Pereira. 2015. Reshaping agri-environmental subsidies: From marginal farming to large-scale rewilding. Basic and Applied Ecology 16(2):95-103.

Moreau, C., C. Barnaud, and R. Mathevet. 2019a. Conciliate Agriculture with Landscape and Biodiversity Conservation: A Role-Playing Game to Explore Trade-Offs among Ecosystem Services through Social Learning. Sustainability 11(2):310.

Moreau, C., C. Barnaud, and R. Mathevet. 2019b. Is the evolution of baseline landscapes a blind spot in the landscape governance ? The example of Mont Lozere, France. Développement durable et territoires 10(2).

Morrison, T. H., W. N. Adger, K. Brown, M. C. Lemos, D. Huitema, J. Phelps, L. Evans, P. Cohen, A. M. Song, R. Turner, T. Quinn, and T. P. Hughes. 2019. The black box of power in polycentric environmental governance. Global Environmental Change 57:101934.

Mottet, A., S. Ladet, N. Coqué, and A. Gibon. 2006. Agricultural land-use change and its drivers in mountain landscapes: A case study in the Pyrenees. Agriculture, Ecosystems, Environment 114(2-4):296-310.

Navarro, L. M. and H. M. Pereira. 2012. Rewilding Abandoned Landscapes in Europe. Ecosystems 15(6):900-912.

North, D. 1991. Institutions. Journal of Economic Perspectives 5(1):97-112.

O'Rourke, E., M. Charbonneau, and Y. Poinsot. 2016. High nature value mountain farming systems in Europe: Case studies from the Atlantic Pyrenees, France and the Kerry Uplands, Ireland. Journal of Rural Studies 46:47-59.

Ockwell, D. and Y. Rydin. 2006. Conflicting discourses of knowledge: Understanding the policy adoption of pro-burning knowledge claims in Cape York Peninsula, Australia. Environmental Politics 15(3):379-398.

Ostrom, E. 2014. Do institutions for collective action evolve? Journal of Bioeconomics 16(1):3-30.

Otero, I., J. Marull, E. Tello, G. L. Diana, M. Pons, F. Coll, and M. Boada. 2015. Land abandonment, landscape, and biodiversity: questioning the restorative character of the forest transition in the Mediterranean. Ecology and Society 20(2).

Piqueray, J., E. Bisteau, G. Bottin, and G. Mahy. 2007. Plant communities and species richness of the calcacerous grasslands in Southeast Belgium. Belgian Journal of Botany 140(2):157-173.

Pomey, M.-P., S. Morgan, J. Church, P. G. Forest, J. N. Lavis, T. McIntoch, and S. Dobson. 2010. Do provincial drug benefit initiatives create an effective policy lab? The evidence from Canada. Journal of Public Health, Politics, Policy, and Law 35(5):705-742.

Reed, M. S., A. Bonn, W. Slee, N. Beharry-Borg, J. Birch, I. Brown, T. P. Burt, D. Chapman, P. J. Chapman, G. D. Clay, S. J. Cornell, E. D. G. Fraser, J. H. Glass, J. Holden, J. A. Hodgson, K. Hubacek, B. Irvine, N. Jin, M. J. Kirkby, W. E. Kunin, O. Moore, D. Moseley, C. Prell, M. F. Price, C. H. Quinn, S. Redpath, C. Reid, S. Stagl, L. C. Stringer, M. Termansen, S. Thorp, W. Towers, and F. Worrall. 2009a. The future of the uplands. Land Use Policy 26(Supplement 1):S204-S216. 
Reed, M. S., A. Graves, N. Dandy, H. Posthumus, K. Hubacek, J. Morris, C. Prell, C. H. Quinn, and L. C. Stringer. 2009b. Who's in and why? A typology of stakeholder analysis methods for natural resource management. Journal of Environmental Management 90(5):1933-1949.

Ribot, J. C. and N. L. Peluso. 2003. A Theory of Access. Rural Sociology 68(2):153-181.

Rikoon, J. S. 2006. Wild horses and the political ecology of nature restoration in the Missouri Ozarks. Geoforum 37(2):200-211.

Robbins, P. 2004. Political Ecology: A Critical Introduction Blackwell, Malden, MA

Roigé, X. and F. Estrada. 2011. Chapter 5. Socio-economic use of cultural heritage in a Natural Park: the Montseny mountains (Catalonia). Page 233 in X. Roigé and J. Frigolé, editors. Constructing Cultural and Natural Heritage : Parks, Museums ad Rural Heritage. Documenta Universitaria, Spain.

Ruskule, A., O. Nikodemus, R. Kasparinskis, S. Bell, and I. Urtane. 2013. The perception of abandoned farmland by local people and experts: Landscape value and perspectives on future land use. Landscape and Urban Planning 115:49-61.

Schlosberg, D. 2004. Reconceiving Environmental Justice: Global Movements And Political Theories. Environmental Politics 13(3):517-540.

Smart, B. 2002. Michel Foucault: Critical Assessments. Psychology Press.

Soliva, R., K. Rønningen, I. Bella, P. Bezak, T. Cooper, B. E. Flø, P. Marty, and C. Potter. 2008. Envisioning upland futures: Stakeholder responses to scenarios for Europe's mountain landscapes. Journal of Rural Studies 24(1):56-71.

Svarstad, H., T. A. Benjaminsen, and R. Overå. 2018. Power theories in political ecology. Journal of Political Ecology 25.

Vacquie, L. A., T. Houet, T. L. Sohl, R. Reker, and K. L. Sayler. 2015. Modelling regional land change scenarios to assess land abandonment and reforestation dynamics in the Pyrenees (France). Journal of Mountain Science 12(4):905-920.

van der Zanden, E. H., S. M. Carvalho-Ribeiro, and P. H. Verburg. 2018. Abandonment landscapes: user attitudes, alternative futures and land management in Castro Laboreiro, Portugal. Regional Environmental Change 18(5):1509-1520.

Walker, P. A. 2005. Political ecology: where is the ecology? Progress in Human Geography 29(1):73-82.

Warren, C. 2009. Managing Scotland's Environment. Edinburgh University Press, Scotland.

Werritty, A., R. J. Pakeman, C. Shedden, A. Smith, and J. D. Wilson. 2015. A Review of Sustainable Moorland Management. Report to the Scientific Advisory Committee of Scottish Natural Heritage., SNH, Battleby.

Wightman, A. 2013. The Poor Had No Lawyers: Who Owns Scotland and How They Got it. Birnlinn Limited, UK.

Wightman, A., P. Higgins, G. Jarvie, and R. Nicol. 2002. The Cultural Politics of Hunting: Sporting Estates and Recreational Land Use in the Highlands and Islands of Scotland. Culture, Sport, Society $5(1): 53-70$.

Wynne-Jones, S., C. Clancy, G. Holmes, K. Mahony, and K. Ward. 2020. Feral Political Ecologies?: The Biopolitics, Temporalities and Spatialities of Rewilding. Conservation and Society 18(2):71-76.

Wynne-Jones, S., G. Strouts, and G. Holmes. 2018. Abandoning or Reimagining a Cultural Heartland? Understanding and Responding to Rewilding Conflicts in Wales-the Case of the Cambrian Wildwood. Environmental Values 27(4):377-403. 